\title{
FOLK COSTUME IN THE RITUAL YEAR AND BEYOND: HERITAGE, IDENTITY MARKER, AND SYMBOLIC OBJECT
}

\author{
Irina Sedakova, Nina Vlaskina
}

The idea of this issue of Folklore: EJF emerged from the panel we organised on behalf of the Working Group on the The Ritual Year at the 12th Congress of the Société Internationale d'Ethnologie et de Folklore (SIEF) held in Zagreb, Croatia, in June 2015. ${ }^{1}$ We concentrated on the calendric and life cycle usage of the traditional garments and their parts, and we also followed, as much as possible, the new development trends and even the expansion of authentic clothes.

Folk costumes are amongst the most topical and discussed issues in historical and contemporary folklore studies, ethnology, and cultural anthropology, and remain important for many people in many countries. The bibliography on costumes is vast, and it includes huge academic volumes, albums, and articles. Moreover, academic, popular, political, and commercial interest in the garments and their accessories continues to grow. The old pieces of traditional clothes and their replicas are being sought by museums and private collections, for cultural performances, and occasionally they are sold in flea markets, as we saw in Zagreb.

During the past decade, we have witnessed the growth of a number of conferences, ${ }^{2}$ publications and discussions on folk costumes (Kawar 2011; VintilăGhiţulescu 2011; Hulsbosch 2014; Shukla 2015; Eklund 2016, etc.). Also, new developments have taken place in social life regarding the costumes. In this context, we would like to mention the following public festivals that have emerged recently: the National Day of Folk Costume established in Moldova on June 26, 2016; the National Costume Day established in Georgia on May 18, 2016; the All-Ukrainian National Costume Day established in Ukraine in 2015, where it replaced the Annual Parade of the Embroidered Shirt (Vyshivanka). In many countries, such annual festivals are traditional: the International Festival of Folk Costumes in Zheravna (Bulgaria); the National Costume Festival on Männlichen (Switzerland); the National Costume and Clothing Heritage Festival (Kamnik, Slovenia); the Mongolian National Costume Festival and Parade in 
Ulaanbaatar (Mongolia); the Icelandic National Costume Festival; and Sarafan: The Festival of Russian Costume (Russia).

It seems obvious that these new festive activities using the symbolism of costume have appeared in the post-Soviet states, where the necessity of strengthening the national identity is urgent and topical. We have to note, though, that the attitude to and the social value of the folk costumes in the countries of the socialist block, even in the fifteen republics of the USSR, differ. For example, firm traditions to wear traditional costumes have been maintained in the Baltic countries and in the Czech Republic: the Ritual Year group had a wonderful opportunity to see them when the annual conferences were held in the corresponding countries. ${ }^{3}$ Attitudes have changed even in countries not as keen to maintain the authentic traditions. In Bulgaria and Ukraine, for example, an increasing number of people have started to celebrate weddings with the bride and the groom dressed in traditional clothes; there are also new trends to wear parts of folk costumes at school or university graduation ceremonies, etc.

This is explained by the multitude of meanings and functions of traditional national folk clothes and their potential to preserve the cultural heritage and make the identity explicit in a number of ethnographic and religious contexts. It is exploited in various spheres, such as folk-cultural, political, economic, and fashion events. There are many groups on Facebook that discuss and present the most interesting items and examples of various regions for academic and practical purposes and to maintain traditions (cuts of traditional parts of clothes, embroidery, etc). Museums and city exhibitions often display new arrivals and acquisitions.

The beauty and picturesqueness of the national costumes add to the renaissance and growth of interest in them.

The traditional costume is one of the most vibrant elements of cultural heritage and is regarded by ethnologists (e.g. Piotr Bogatyrev) as a semiotic system carrying explicit social, gender, and age differences. In traditional societies, it is so rich in its festive and everyday usage and is correlated with its magical and symbolic properties. Folk dress is an important sign of festive behaviour. In modern societies some ethnic groups still wear their national costumes in an attempt to preserve their cultural heritage and oppose globalisation, revealing an 'us/them' divide. Meanwhile, national dress has developed new social functions and often emphasises political identity issues and commercial purposes (local touristic ethnographic performances, folk festivals). Many traditional costumes and their typical elements (shirts, skirts/kilts, hats, shawls, belts, ornaments) have become fashionable items and spread internationally. 
The aim of the articles in the presented volume is to analyse changes in the symbolism and functions of folk costume as used in the festive calendar year and in everyday life. The texts published in this volume embrace various ethnic and religious traditions of different places and epochs.

Focusing on the issues discussed and the chronological scope of the studies, we can divide the contributions made to this volume into several groups. In one of them, issues related to the changes taking place in traditional costumes and their role in society at different historical stages are put forward.

The article co-authored by Alexander Novik and Andrey Sobolev, and the articles by Anamaria Iuga and Nina Vlaskina reflect this aspect. As the congress took place in Croatia, many scholars concentrated on the local costumes of the Balkan and South Slavic region - Croatia, Montenegro, Serbia, Bulgaria, and Romania. The articles by Marija Gačić and Urszula Wilk discuss the traditional costume competitions and stress the issues associated with the interpretation of the terms 'tradition' and 'authenticity', the parameters used to assess costumes, and the role of the costume in the preservation of cultural heritage. The semiotic and pragmatic functions of garments come to the fore in the articles by Cristina Clopot and Irina Sedakova, and in the article co-authored by Britt Eklund and Katarina Ek-Nilsson. Finally, the papers by Milana Černelić and Rosa Isela Aguilar Montes de Oca are aimed at analysing recent cultural processes, including the revitalisation of festivities and invention of new garments based on traditional knowledge.

Alexander Novik and Andrey Sobolev describe in detail and analyse the wedding costume of the Mrkovići Muslim ethno-local group in Montenegro. They consider folk costume as an important part of tangible heritage and describe the historical changes of the elements of women's garments and their dialectal names. The authors reveal the transformation of the garments under the influence of Islamic fashion at the early stage and that of European fashion at a later time. They examine not only the sources of innovation and selection of costume elements but also the development of cultural preferences; they also characterise the local specificity of the Mrkovići wedding costume.

A diachronic approach to the study of traditional clothing also forms the basis of Anamaria Iuga's research. She analyses the festive costume from the Maramureş region (Romania), identifying scenarios of cultural dynamics and influential factors. The author traces the change of the material used for making clothes (from homespun to naturally manufactured, and then to synthetically manufactured). Anamaria shows how one traditional model is replaced by another, when the elements of the costume adopted from neighbouring cultures 
are considered as typical for the host country in the course of time. She also investigates the influence of the mass media on the unification of costumes and how the surviving elements represent the local identity and the continuation of traditions at the cost of losing the costume as a complex.

The articles by Marija Gačić and Urszula Wilk raise similar problems. Both authors consider how traditional garments are presented at contests, and how the assessment procedure and selection of the best costume are carried out. Marija Gačić depicts several beauty elections in traditional costumes in Croatia, and Urszula Wilk examines the specially sewn traditional festive clothes, worn by the participants in the annual feast las Fallas in Valencia (Spain). A wide range of issues concerning the contest procedure itself and the costumes displayed in public are scrutinised. In particular, they discuss the different use of the terms 'authentic' and 'traditional' by the contest participants and professional ethnographers, and they describe the situations when the jury has to prioritise and choose between the costumes of different historical periods. The rules for assessing costumes are another topical issue.

Urszula Wilk concludes that the development of the documentation for the contest leads to the codification of costumes and reduces the diversity of traditions. Marija Gačić describes another situation when some rules exist but are not recorded anywhere, rendering the degree of subjectivity, as well as the responsibility of the appointed experts, in the decision-making process very high. The authors also draw attention to the change in the roles of participants at the events. In the case of las Fallas, the new aim of a folkloric presentation of the local culture to tourists and the active participation of costumed women in a contemporary festival deflect attention from the main part of the event burning of the specially-built monument falla. Marija Gačić describes the new type of participants in the selection of beautiful objects, namely, the collectors, and poses the question whether one may place under one umbrella both the members of the traditional communities presenting the cultural heritage of their families and those who perceive tradition only as subject to third-party admiration.

The unique diversity and the high degree of preservation of traditional garments in the Swedish parish of Boda (the county of Dalecarlia) are depicted in the article by Britt Eklund and Katarina Ek-Nilsson. The authors examine the conditions of the long-term preservation of traditions, stressing the equality of the parishioners with respect to property and social status, as well as the active use of the identity presentation function. During long-term work outside the home village, for the representatives of the local community, the costume became a way to maintain ties with their homeland. They also explore the new contexts of the existence of this unique costume complex in modern conditions, 
when in other parts of the country the traditional costume has been lost. In the countryside, interest in the traditional heritage has increased, and the aesthetic and semiotic functions of costumes have moved to the forefront; and in certain contexts, the costumes of the parish of Boda have come to represent Swedish folk costumes in general.

The symbolic functions of costumes, which are relevant to magical rites and daily life from infancy and later, are characterised in Irina Sedakova's paper. The author explores the traditional Slavic semiotic opposition of the bareness of a new-born child (as a sign of the lack of its social links) and its first clothes. Each piece of the baby's garments is seen as a bearer of a symbolic meaning and is used in the ritual setting to facilitate the socialisation of the baby, to guard it from evil spirits and illnesses, to help it develop some positive qualities, etc. The clothes of adults also acquire specific features in the context of the authentic birth-lore, which in many ways are forgotten and not used in the modern society.

Two articles in the volume analyse the dynamics of costumes in the enclaves of Russian Old Believers living outside their historical homeland, particularly in Romania and Turkey.

Cristina Clopot examines the transformation of the traditional garments of Russian Old Believers (Lipovene) in Romania through the prism of identity representation. The author demonstrates the close connection between wearing the traditional costume and the value system and moral orientations of the society. In particular, Cristina reveals how the concept of purity is reflected in the division of clothing appropriate for the secular and church context in a symbolic interpretation of certain elements of the costume (for example, a woven belt). The author describes in detail the wedding dress of Old Believers and the symbolic meaning of its elements. She shows how the substitution of a locally specific costume by a stereotypical version of Russian clothes has occurred in public performances related to the representation of the cultural heritage. She also traces the change in the status of traditional clothing in modern conditions and the reduction of its value in the community.

Nina Vlaskina investigates the dynamics of the festive clothes of the other group of Russian Old Believers settled in Turkey - the Cossacks, named after their leader, Ignat Nekrasov, who took them away from religious and political persecution. Nina traces the history of the formation of their costume complex, the influence of other ethnic groups, and the gradual narrowing of the costume's functions after their return to their homeland and the environment of ethnically related neighbours. She concentrates on the conditions and the stages of the loss of traditional garments and amply discusses their role as a representa- 
tive of the group's heritage in the context of museum exhibitions, folk group performances, and souvenir production.

Milana Černelić examines the role of costumes in the revival of the traditional rituals in a group of Bunjevci Croats in Serbia. Wearing traditional costumes becomes mandatory for participation in the celebrations during the Shrovetide period (Prelo), Pentecost Pageant, and the harvest festival (Dužijanca), while in other contexts traditional costume is now hardly ever used. The author dwells on the changes caused by the desire to make the costume more comfortable (simplification of the heavy headdress of kraljice), as well as the transformation of the functions of garments (the use of working clothes and underwear as festive attire).

Rosa Isela Aguilar Montes de Oca discusses the theme of inventing a costume and shows the connection between two opposing processes in the strengthening of local identity: activities aimed at the preservation and promotion of a common cultural heritage, on the one hand, and the invention of a new costume, as well as a search for new ways to draw attention to the local heritage, on the other hand. The author characterises the celebration of the Day of the Dead in La Huasteca region (Mexico) and describes the actions of the locals concerned with the problems of cultural specificity to protect their ritual practices against the impact of globalisation, the United States, and their closest neighbours.

A brief review of the articles presented in this thematic volume reveals a range of issues common to different religious and ethnic groups related to the historical development and current existence of the traditional garments. Most of the authors illustrate the idea that costume is a valuable means of expressing identity. They also underline the increased interest of society in folk costumes both in the folk calendar and life-cycle celebrations and festivals. Most of the articles underline the details created and invented in the authentic garments today, and discover the influence of the clothes on national fashion trends. In the conditions of varying degrees of costume preservation in different areas, which is due to historical and socio-economic factors, women's costumes are usually better preserved than men's, while festive costumes are better preserved and more symbolic than everyday costumes. The studies also show the irreversible effect of industrialisation on manufacturing, technological processes, priorities in the use of materials, unifying processes, and the loss of local diversity in some areas. The valuable conclusion is drawn that when part of the elements fade into oblivion and are replaced with their modern counterparts, the 'survivors' acquire primary symbolic value and start to represent the costume tradition as a whole and sometimes even the entire cultural heritage of the group. 
This issue cannot cover or even touch upon all the aspects of symbolism and heritage-related issues specific to festive clothes in various churches and confessions. Many topical issues still need to be discussed, especially as we bear in mind the high rate of migration and the co-existence of typical traditional religious garments in Europe and the political discussions around it. There are interesting prospects for studying folk dresses in their historical and modern 'new' life, which in some countries and regions has taken the form of a folk renaissance.

\section{NOTES}

1 About a detailed review of the 12th SIEF Congress see Vlaskina et al. 2015.

2 See, for example, Conference on Dress, Popular Culture and Social Action in Africa (Northwestern University, Evanston, USA, 13-14.03.2009); In Between: Culture of Dress between East and West. The 64th Annual Conference of the International Committee for Museums and Collections of Costume (Belgrade, Serbia, 25-30.09.2011); Living Folk Costume (Estonian Folk Art and Craft Union, Tartu, Estonia, 14-15.09.2012); The Historical Dynamics of the Traditional Costume of the Peoples of Russia: International Conference (State Republican Centre of Russian Folklore, Moscow, Russia, 25-27.11.2015); Folk Costume in Siberia: All-Russian Conference (Institute of Archaeology and Ethnography of the Siberian Branch of the Russian Academy of Sciences, 27-29.10.2016).

3 See, for example, The Ritual Year 3 (Sedakova 2008) in the Czech Republic, where the cover shows beautiful garments during the ritual "The Ride of the King", observed by the participants of the conference.

\section{REFERENCES}

Eklund, Britt 2016. Dräktalmanacka: Boda socken, Dalarna. [Dressing Calendar of the Boda Parish, Dalarna.] Uppsala: Institutet för språk och folkminnen. Available at http://www.sprakochfolkminnen.se/download/18.5a7af053153e51c32cb24 ee/1461082008459/Dra\%CC\%88ktalmanacka+Boda+socken+Dalarna.pdf, last accessed on November 7, 2016.

Hulsbosch, Marianne 2014. Pointy Shoes and Pith Helmets: Dress and Identity Construction in Ambon from 1850 to 1942. Leiden \& Boston: Brill. DOI: 10.1163/9789004260818.

Kawar, Widad Kamel 2011. Threads of Identity: Preserving Palestinian Costume and Heritage. Limassol: Rimal Publications.

Sedakova, Irina (ed.) 2008. The Ritual Year 3: The Ritual Year and History. Proceedings of the Third International Conference of the SIEF Working Group on the Ritual Year. Strážnice, Czech Republic, May 25-29, 2007. Strážnice: Národní ústav lidovè kultury. 
Shukla, Pravina 2015. Costume: Performing Identities through Dress. Bloomington, IN: Indiana University Press.

Vintilă-Ghiţulescu, Constanţa 2011. From Traditional Attire to Modern Dress: Modes of Identification, Modes of Recognition in the Balkans (XVIth-XXth Centuries). Newcastle upon Tyne: Cambridge Scholars Publishing.

Vlaskina, Nina \& Ermolin, Denis \& Novik, Aleksandr \& Ryzhakova, Svetlana \& Sedakova, Irina 2015. Utopii, real'nost' i kul'turnoe nasledie v etnografii XXI v. [Utopias, Realities, and Heritage in the Ethnographies of the 21st Century.] Antropologicheskii forum, Vol. 27, pp. 251-273. Available at http://anthropologie. kunstkamera.ru/files/pdf/027/congress_sief.pdf, last accessed on November 7, 2016 . 